\title{
Pseudovivipary, a new form of asexual reproduction in the seagrass Posidonia oceanica
}

\author{
Enric Ballesteros ${ }^{1, *}$, Emma Cebrian', Antoni \\ Garcia-Rubies', Teresa Alcoverro', Javier \\ Romero $^{2}$ and Xavier Font ${ }^{3}$
}

${ }^{1}$ Centre d'Estudis Avançats de Blanes (CSIC), Acc. Cala Sant Francesc, 14, 17300 Blanes, Spain, e-mail: kike@ceab.csic.es

2 Departament d'Ecologia, Facultat de Biologia,

Universitat de Barcelona, Diagonal 645, 08028

Barcelona, Spain

${ }^{3}$ Departament de Botànica, Facultat de Biologia,

Universitat de Barcelona, Diagonal 645, 08028

Barcelona, Spain

${ }^{*}$ Corresponding author

\begin{abstract}
The seagrass Posidonia oceanica is able to reproduce by asexual formation of plantlets directly in the inflorescence. Pseudoviviparous plantlets were observed during May 2004 in $26 \%$ of the inflorescences in a P. oceanica meadow off the island of Formentera (Balearic Islands, Western Mediterranean Sea). We do not know how frequently pseudovivipary occurs in Posidonia oceanica, nor the mechanisms triggering it, but this strategy can contribute significantly to short-distance dispersal and meadow maintenance, which is especially relevant in a species whose meadows can persist for thousands of years and whose colonization of new space occurs very slowly.
\end{abstract}

Keywords: dispersal; Posidonia; pseudovivipary; seagrass; reproduction.

Seagrasses can disperse by sexual reproduction (through hydrodynamic transport of fruits) and asexually by transport of detached shoots (Capiomont et al. 1996). Here we report on the first evidence of a novel reproductive strategy in seagrasses, by asexual formation of plantlets directly in the inflorescence. This has been found in the Mediterranean endemic species Posidonia oceanica (L.) Delile (which has limited dispersal capacities) and our observations may open new views on the mechanisms of plant dispersal and meadow persistence.

Growth of plantlets in flowers is called vivipary, and is defined as the continuous growth of the offspring when still attached to the maternal parent (Goebel 1905). Two kinds of vivipary have been identified: true vivipary, in which seeds resulting from sexual reproduction germinate before they are shed from the plant, and pseudo- vivipary when asexual propagules such as bulbils or plantlets replace sexual reproductive structures (Elmqvist and Cox 1996). While vivipary has been described in mangroves and some seagrasses (Amphibolis, Thalassodendron) (Tomlinson 1986, Kuo and Kirkman 1990), our observations are the first report of pseudovivipary in marine plants.

We observed pseudovivipary to be abundant in a seagrass meadow of Posidonia oceanica thriving in the west side of the islet of Espardell (Formentera, Balearic Islands, western Mediterranean Sea, 38 47'50 N, $1^{\circ} 28^{\prime} 32 \mathrm{E}$ ), between 3 and $10 \mathrm{~m}$ depth (Figure 1a). Posidonia oceanica reproduces clonally by shoot division as well as sexually by three to five hermaphroditic and male flowers arranged in a terminal inflorescence or spike (den Hartog 1970). Flowering occurs only occasionally in Posidonia oceanica meadows, showing large and unpredictable variations both in space and time (Caye and Meinesz 1984, Balestri and Valerini 2003). Flowers were exceptionally abundant (approximately $28 \%$ of shoots) in the seagrass meadow of Espardell in October 2003, and large amounts of fruits were produced in early 2004 . In May 2004 we observed mature fruits in 18\% of the inflorescences, and pseudoviviparous plantlets in $26 \%$, while $55 \%$ of the inflorescences bore neither fruits nor plantlets. Finding of both plantlets and fruits in the same shoot (three out of 1463 spikes counted bore one fruit and one to three small plantlets; Figure 1b) indicates that pseudovivipary is facultative. These data were obtained examining 30 randomly placed $40 \times 40 \mathrm{~cm}$ quadrats. Some detached inflorescences bearing plantlets were also observed on nearby sandy bottoms, although at this date there were no distinguishable roots coming out from the plantlets. However, at the end of July, $5 \%$ of the plantlets developed roots when still attached to the parental plants. Root development was much more abundant (32\%) in inflorescences detached from the parental shoots, lying on nearby sandy bottoms (Figure 1c). We observed pseudovivipary to be present in other seagrass meadows off Formentera and Eivissa, close to the study site, but at much lower densities. We did not find any sign of pseudovivipary in other seagrass meadows situated off the continental coasts of Spain, nor in the Balearic island of Menorca, where regular monitoring studies were carried out during 2004.

Observed plantlets unequivocally came from leafy spikelets located in the upper portion of the inflorescence. That these plantlets originated from fertilized carpels can be discounted, since no remains of them (as would be the case in true vivipary) were found after exhaustive observation. The numbers of plantlets in each pseudoviviparous spike ranged from 2 to 6 , with an average of 3.7 plantlets per spike $(n=35)$. At the end of 


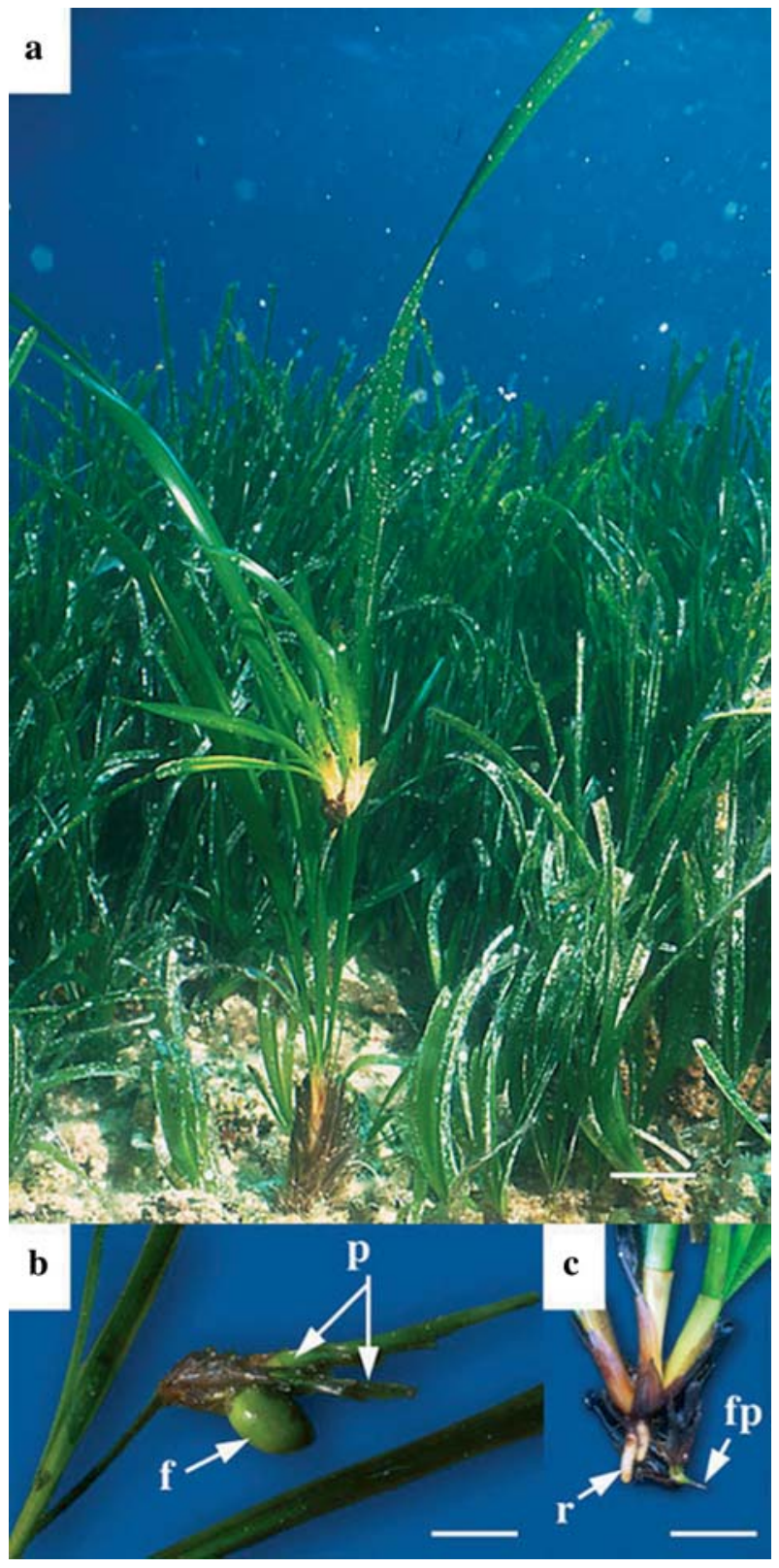

Figure 1 Pseudovivipary in the seagrass Posidonia oceanica. (a) In situ aspect of pseudoviviparous plantlets still attached to the parental shoot. Scale bar $4 \mathrm{~cm}$. (b) Inflorescence with one fruit and two small pseudoviviparous plantlets. f: fruit, p: plantlets. Scale bar $2 \mathrm{~cm}$. (c) Detail of the basal part of a detached inflorescence showing three pseudoviviparous plantlets and two incipient roots. r: roots, fp: floral peduncle. Scale bar $2 \mathrm{~cm}$.

May, each plantlet bore an average of 4.2 leaves, with some of them measuring up to $30 \mathrm{~cm}$ long, and were fully green and with the same morphology as those from standing shoots.

Several non-heritable inducers of pseudovivipary are known to be triggered through environmental changes, fungal infection or water stress (Beetle 1980, Clay 1986, Pierce et al. 2003). Abnormally high temperatures were detected in summer 2003, resulting in the hottest summer of the last 500 years (Luterbacher et al. 2004). But, the link between warm waters and pseudovivipary appears only circumstantial, and nothing can be concluded about the signal triggering plantlet production.
Whatever the trigger that induces facultative pseudovivipary in Posidonia oceanica, this capacity adds a new perspective to the reproductive and dispersal features of this species. Posidonia oceanica dispersal was known previously to occur only through hydrodynamic transport of fruits and detached shoots. By means of facultative pseudovivipary, Posidonia oceanica conducts both sexual and asexual reproduction during the flowering event. The plant takes advantage simultaneously of fruit and seed production (maintaining genetic diversity and ensuring long-range dispersal), and enhanced production of new shoots (maintaining parent genotype, short-range dispersal). Although we currently do not know how frequently pseudovivipary occurs in Posidonia oceanica, nor the mechanisms triggering it, the fact that it happens occasionally suggests that it may contribute significantly to short-distance dispersal and persistence in a species of great ecological importance, whose meadows can persist for thousands of years (Mateo et al. 1997) and whose colonization of new space occurs very slowly (Meinesz and Lefevre 1984).

\section{Acknowledgements}

We are indebted to J. Asensio and I. Maggiulli for diving assistance and to E. Sala for his helpful comments on the manuscript. This work was supported by the Fisheries Department (Direcció General de Pesca) of the Balearic Government.

\section{References}

Balestri, E. and F. Vallerini. 2003. Interannual variability in flowering of Posidonia oceanica in the north-western Mediterranean Sea, and relationships among shoot age and flowering. Bot. Mar. 46: 525-530.

Beetle, A.A. 1980. Vivipary, proliferation and phyllody in grasses. J. Range Manage. 33: 256-261.

Capiomont, A., M. Sandmeier, G. Caye and A. Meinesz. 1996. Enzyme polymorphism in Posidonia oceanica, a seagrass endemic to the Mediterranean. Aquat. Bot. 54: 265-277.

Caye, G. and A. Meinesz. 1984. Observations sur la floraison et la fructification de Posidonia oceanica dans la baie de Villefranche et en Corse du Sud. In: (C.F. Boudouresque, A. Jeudy de Grissac and J. Olivier, eds) First international workshop on Posidonia oceanica beds. GIS Posidonie, Marseille. pp. 193-201.

Clay, K. 1986. Induced vivipary in the sedge Cyperus virens and the transmission of the fungus Balansia cyperi (Clavicipitaceae). Can. J. Bot. 64: 2984-2988.

den Hartog, C. 1970. The seagrasses of the world. North-Holland Publication Co., Amsterdam. pp. 275.

Elmqvist, T. and P.A. Cox. 1996. The evolution of vivipary in flowering plants. Oikos 77: 3-9.

Goebel, K. von. 1905. Organography of plants, especially of the Archegoniatae and Spermatophyta. Oxford University, Oxford. Volume 1. General organography. pp. 270. Volume 2. Special organography. pp. 707.

Kuo, J. and H. Kirkman. 1990. Anatomy of viviparous seagrasses seedlings of Amphibolis and Thalassodendron and their nutrient supply. Bot. Mar. 33: 117-126.

Luterbacher, J., D. Dietrich, E. Xoplaki, M. Grosjean and H. Wanner. 2004. European seasonal and annual temperature variability, trends and extremes since 1500. Science 303: 1499-1503. 
Mateo, M.A., J. Romero, M. Pérez, M.M. Littler and D.S. Littler. 1997. Dynamics of millenary organic deposits resulting from growth of the Mediterranean seagrass Posidonia oceanica. Estuar. Coast. Shelf Sci. 44: 103-110.

Meinesz, A. and J.R. Lefevre. 1984. Regeneration of a Posidonia oceanica bed forty years after its destruction by a bomb in Villefranche Bay (Alpes Maritimes, France). In: (C.F. Boudouresque, A. Jeudy de Grissac and J. Olivier, eds) First international workshop on Posidonia oceanica beds. GIS Posidonie, Marseille. pp. 39-44.
Pierce, S., C.M. Stirling and R. Baxter. 2003. Pseudoviviparous reproduction of Poa alpina L. (Poaceae) during long-term exposure to elevated atmospheric $\mathrm{CO}_{2}$. Ann. Bot. 91: 613-622.

Tomlinson, P.B. 1986. The botany of mangroves. Cambridge University, London. pp. 413.

Received 25 January, 2005; accepted 22 March, 2005 